www.jmscr.igmpublication.org

Impact Factor (SJIF): 6.379

Index Copernicus Value: 79.54

ISSN (e)-2347-176x ISSN (p) 2455-0450

crossrefDOI: https://dx.doi.org/10.18535/jmscr/v6i8.173

Journal Of Medical Science And Clinical Research

IGM Publication

An Official Publication of IGM Publication

\title{
Prevalence and determinants of internet addiction among undergraduate medical students of Rewa, M.P.
}

\author{
Authors \\ Dr Prayank Jain ${ }^{1}$ DM, Dr Achla Jain² MBBS \\ Corresponding Author \\ Dr Prayank Jain
}

C/o Shri A.K. Jain 109/2B Nehru Nagar Colony, Opp. Medical College Jabalpur, Madhya Pradesh, India

\begin{abstract}
Background: Recent increase in ease to internet availability, its low cost and emergence of many social media apps have jointly resulted in exponential increase in use of internet specially among youngsters like medical students due to their social and academic needs.

Objectives: To assess prevalence of Internet addiction among undergraduate medical students \& to assess determinants of internet addiction.

Materials and Methods: This was a cross sectional study conducted among 150 undergraduate medical students of SS Medical College Rewa, MP. This study was conducted between 1/7/2017 to 31/8/2017 Study subjects were selected randomly \& asked to complete Youngs IAT questionnaire in lecture theatre.

Results: Among 150 study participants, 50.6\% were males and 49.4\% were females. The prevalence of internet addiction among the study subjects in the present study was 93.3\%. 38.7\% had mild internet addiction, 49.3\% had moderate internet addiction \& $5.3 \%$ had severe internet addiction. $6.7 \%$ students reported normal internet usage. Difference in prevalence of internet addiction among males and females was found statistically non significant $(p=>0.05)$. Factors associated with internet addiction were staying in hostel and living single, usage of smart phone, preferring online shopping and online studying.

Conclusion: Undergraduate medical students have an increased prevalence of internet addiction. Efforts to increase awareness about bad effects of internet addiction and intervention measures to prevent this is urgent need of time.

Keywords: Internet Addiction, Youngs IAT score, Medical Students.
\end{abstract}

\section{Introduction}

In the new generation, the internet has become an important tool for education, entertainment, communication, and information-sharing. Recent increase in ease to internet availability has resulted in exponential increase in use of internet specially among students due to their social and academic needs. Easy access and social networking are two of the several aspects of the
Internet fostering addictive behaviour. ${ }^{1}$ In tandem with the splurge in access to the Internet globally, with the rise of new-generation gadgets, the risk of "internet addiction" is emerging as a significant behavioral addiction pandemic to be tackled worldwide. ${ }^{2}$ The developing countries are not spared either due to extreme infiltration of technology even into the remotest corners. 
The fascinating world of internet originated in the 1960's, when the United States used it for military purposes for the first time.$^{3}$ Today, in terms of internet usage, India ranks second with 354 million internet users, ahead of many other countries including the United States (280.7 Million $)^{4}$. Internet addiction is a growing problem and is known by different terms such as pathological internet use ${ }^{5}$, Problematic internet use $^{6}$, compulsive internet use $^{7}$ and Internet Overuse $^{8}$. Among the different age groups, students who struggle to cope up with academic performance or have peer and behavioral concerns are more susceptible to internet addiction. The overall global prevalence of internet addiction as $6 \%{ }^{9}$, while it is $0.7 \%^{10}$ to $18.88 \%{ }^{11}$ in India. There is a paucity of large sample studies on internet addiction and its determinants from India, a country with huge adolescent population.

India is the second largest online market in the world ranked only behind china. As of January 2017 India had 462.1 million internet users, of which 442.7 million were mobile internet users. By 2021 there will be about 635.8 million internet users in india. ${ }^{12}$ Recent increase in ease to internet availability, its low cost and emergence of many social media apps have jointly resulted in exponential increase in use of internet specially among youngsters like medical students due to their social and academic needs.

\section{Material and Methods}

Definitions: Internet users: An internet user is defined as "someone aged 2 years and above who went online in the past 30 days". The definition is based on the International Telecommunication Union (ITU) definition as quoted by Internet World Stats (2014) ${ }^{13}$.

Internet Addiction by Young's IAT: The severity of impairment is based on the final score obtained by summation of the individual scores and classified as internet addicted.

The study instrument was a questionnaire with three part:

1. Socio-demographic information.
2. Details regarding patterns and determinants of internet use.

3. Young's Internet Addiction Test (IAT). Young's internet addiction test is a self-rated scale developed for screening and measuring level of internet addiction and has been used extensively for this purpose worldwide. It contains twenty questions related to internet usage to be scored on Likert scale from 1 (rarely) to 5 (always). A total score of $<20$ represents normal user, between 20 and 49 represents mild addiction, between 50 and 79 represents moderate addiction, between 80 and 100 represents severe addiction. The validity and reliability of Young's internet addiction scale has been tested in many studies. ${ }^{[14,15]}$ Its reliability in Indian population and college students has also been established. ${ }^{[16,17]}$

This was a cross sectional study conducted among 150 undergraduate medical students of SS Medical College Rewa, MP. This study was conducted between $1 / 7 / 2017$ to $31 / 8 / 2017$. Study subjects were selected randomly \& asked to complete a pre-designed proforma which included socio-demographic variables and Youngs IAT questionnaire in lecture theatre. Subjects with Youngs IAT score of $<20$ were classified as having no internet addiction, score 20-49 as mild, score 50-79 as moderate and score $>80$ was classified as severe or high internet addiction. Subjects with known psychiatric disorders, not having any kind of personal internet mode (i.e. no personal smart phones ,no laptops, no tablets) and not willing to participate were excluded from the study. Students who were absent on the day of data collection were also excluded.

Random sampling technique was done for selecting the target study participants. In case of doubt, they were clarified and students were made to complete the questionnaire by them self. All students were assured that the information collected would be treated confidentially, and anonymity will be maintained.

\section{Statistical Analysis}

Statistical analysis of data was carried out by using SPSS and Chi-square test to analyze 
qualitative variables and one-way ANOVA to analyse quantitative variables. A value of $P<0.05$ was considered significant for all statistical correlations. Sociodemographic variables and patterns of Internet use have been denoted by frequency tables. The prevalence of Internet addiction were described in terms of percentage. Descriptive statistics were used to examine the association of factors of the questionnaire with Internet addiction.

\section{Result}

Socio demographic Characteristic of the study population and pattern of Internet use are depicted in [Table 1] and [Table 2].

Table 1 Socio demographic characteristics of study participants

\begin{tabular}{|c|c|c|}
\hline Socio demographic variable & No. & $\%$ \\
\hline \multicolumn{3}{|l|}{ 1. Gender } \\
\hline Male & 76 & $50.6 \%$ \\
\hline Female & 74 & $49.4 \%$ \\
\hline \multicolumn{3}{|l|}{ 2. Fathers occupation } \\
\hline Government & 80 & $53.3 \%$ \\
\hline Private & 22 & $14.7 \%$ \\
\hline Self employed & 18 & $12 \%$ \\
\hline Professional & 6 & $4 \%$ \\
\hline Business & 24 & $16 \%$ \\
\hline \multicolumn{3}{|l|}{ 3. Mothers occupation } \\
\hline Government & 18 & $12 \%$ \\
\hline Private & 8 & $5.3 \%$ \\
\hline Self employed & 2 & $1.3 \%$ \\
\hline Professional & 0 & 0 \\
\hline Business & 0 & 0 \\
\hline Home Maker & 122 & $81.3 \%$ \\
\hline \multicolumn{3}{|l|}{ 4. Place of stay } \\
\hline Home & 12 & $8 \%$ \\
\hline Paying guest & 34 & $22.7 \%$ \\
\hline Hostel & 54 & $36 \%$ \\
\hline \multicolumn{3}{|l|}{ 5. Living status } \\
\hline Alone & 40 & $26.7 \%$ \\
\hline sharing room & 110 & $73.3 \%$ \\
\hline
\end{tabular}

Table 2 Patterns and modes of internet Use

\begin{tabular}{|c|c|}
\hline Variables & $\mathbf{N}(\%)$ \\
\hline \multicolumn{2}{|l|}{ Years of internet use } \\
\hline $1-5 y$ & $118(78.7 \%)$ \\
\hline $6-10 y$ & $30(20 \%)$ \\
\hline $11-15 y$ & $2(1.3 \%)$ \\
\hline \multicolumn{2}{|l|}{ Expenditure on internet per month } \\
\hline$<$ Rs. 300 & $110(73.3 \%)$ \\
\hline $300-600$ & $40(26.7 \%)$ \\
\hline$>$ Rs. 600 & $0(0 \%)$ \\
\hline \multicolumn{2}{|c|}{ Most Commonly used gadget for accessing interne } \\
\hline Tablet & $0(0 \%)$ \\
\hline Smart phone & $150(100 \%)$ \\
\hline Laptop and smart phone & $28(18.7 \%)$ \\
\hline Desktop and smart phone & $2(1.3 \%)$ \\
\hline \multicolumn{2}{|l|}{ Login status } \\
\hline $\begin{array}{l}\text { Log in and off occasionally during } \\
\text { the day }\end{array}$ & $46(30.7 \%)$ \\
\hline Permanently online & $104(69.3 \%)$ \\
\hline \multicolumn{2}{|c|}{ *Most commonly used App for internet use } \\
\hline Face Book & $141(94 \%)$ \\
\hline Messenger & $98(65.3 \%)$ \\
\hline Whats app & $150(100 \%)$ \\
\hline Google searching & $150(100 \%)$ \\
\hline yahoo chatting & $49(32.7 \%)$ \\
\hline Others & $61(40.7 \%)$ \\
\hline
\end{tabular}

Among 150 study participants, $50.6 \%$ were males and $49.4 \%$ were females. The prevalence of internet addiction among the study subjects in the present study was $93.3 \%$. $38.7 \%$ had mild internet addiction, $49.3 \%$ had moderate internet addiction \& 5.3\% had severe internet addiction. $6.7 \%$ students reported normal internet usage.

Table 3 Distribution of participants as per IAT Score

\begin{tabular}{|c|c|c|c|}
\hline $\begin{array}{l}\text { Scale \& category of internet } \\
\text { addiction }\end{array}$ & Male (N=) \% & Female(N=) \% & $\begin{array}{c}\text { Prevalence } \\
\text { (CI 95\%) }\end{array}$ \\
\hline Normal ( 0- 19) & $(4) 5.3 \%$ & $(6) 11 \%$ & $(10) 6.7 \%$ \\
\hline Mild (20-49) & $(34) 45 \%$ & $(24) 32.4 \%$ & $(58) 38.7 \%$ \\
\hline Moderate ( 50-79) & $(32) 42.1 \%$ & $(44) 59.4 \%$ & $(76) 49.3 \%$ \\
\hline Severe ( 80-100) & $(6) 7.9 \%$ & $(0) 0 \%$ & $(6) 5.3 \%$ \\
\hline Total (76) & $(74)$ & $(150) 100 \%$ \\
\hline
\end{tabular}

Amongst the various causes for internet addiction, chatting, You tube users, Pornography, Online movies, academic work, online games, online friendship, online shopping are found as the main factors associated with internet addiction. Percentage of addiction amongst the users is depicted in table 4. 
*Table 4: causes of internet addiction

\begin{tabular}{|l|c|c|c|c|c|}
\hline Variable & Normal & Mild IA & Moderate IA & Severe IA & Total \\
\hline Chatting & $10(6.7 \%)$ & $58(38.7 \%)$ & $76(50.6 \%)$ & $6(4 \%)$ & $150(100 \%)$ \\
\hline Using internet for academic work & $6(5.7 \%)$ & $40(38.4 \%)$ & $52(50 \%)$ & $6(5.7 \%)$ & $104(69.3 \%)$ \\
\hline Games & $4(6.5 \%)$ & $7(11.3 \%)$ & $47(76 \%)$ & $4(6.4 \%)$ & $62(41.3 \%)$ \\
\hline Online friendship/relationship & $5(3.5 \%)$ & $20(14.1 \%)$ & $45(32 \%)$ & $6(4.3 \%)$ & $141(94 \%)$ \\
\hline Shopping & $1(1.1 \%)$ & $39(45 \%)$ & $42(48.3 \%)$ & $5(5.7 \%)$ & $87(58 \%)$ \\
\hline Pornography & $0(0 \%)$ & $5(22.7 \%)$ & $16(72.7 \%)$ & $3(13.6 \%)$ & $22(14.7 \%)$ \\
\hline You tube & $10(6.7 \%)$ & $58(38.7 \%)$ & $76(50.6 \%)$ & $6(4 \%)$ & $150(100 \%)$ \\
\hline Online Movies & $2(2.12 \%)$ & $20(21.3 \%)$ & $66(70.2 \%)$ & $6(6.4 \%)$ & $94(62.7 \%)$ \\
\hline
\end{tabular}

*multiple choices

Many factors were found to be associated with internet addiction like staying in hostel and living single, usage of smart phone, preferring online shopping and studying.

Difference in prevalence of internet addiction among males and females was found statistically non significant $(p=>0.05)$.

\section{Conclusion}

Undergraduate medical students have an increased prevalence of internet addiction. Efforts to increase awareness about bad effects of internet addiction and intervention measures to prevent this is urgent need of time.

\section{Sponsorship: Nil}

\section{Conflict of interest: Nil}

\section{References}

1. Kuss DJ, Griffiths MD. Online social networking and addiction - A review of the psychological literature. Int $\mathbf{J}$ Environ Res Public Health 2011;8:3528-52.

2. Christakis DA. Internet addiction: A $21^{\text {st }}$ century epidemic? BMC Med 2010;8:61

3. The Invention of the Internet. Available at: http://www.history.com/topics/inventions/inv ention-of the internet Accessed on 28th Dec, $2016 . \quad$ Archived at: http://www.webcitation.org/6n6mczGLp.

4. Top 20 countries with highest number of internet users June 30, 2016. http://www.internetworldstats.com/top20.ht m. Accessed on 15th Dec, 2016. Archived at: http://www.webcitation.org/6mlfdoBj
5. Davis RA. A cognitive-behavioral model of pathological Internet use (PIU). Computers in Human Behavior 2001;17:187-195. http://psycnet.apa.org/doi/10.1016/S07475632(00)00041-8.

6. Caplan SE. Relations among loneliness, social anxiety, and problematic Internet use. Cyberpsychol Behav. 2007 Apr;10(2):23442. PubMed PMID: 17474841.[PubMed]

7. Meerkerk GJ. et al. "The Compulsive Internet Use Scale (CIUS)". Cyber Psychology \& Behavior 2009;12:1-6. doi:10.1089/cpb.2008.0181

8. Rosen LD. et al. iDisorder: Understanding Our Obsession with Technology and Overcoming Its Hold on Us. New York: Palgrave Macmillan; 2012.

9. Cheng $\mathrm{C}, \mathrm{Li} \mathrm{AY}$. Internet addiction prevalence and quality of (real) life: a metaanalysis of 31 nations across seven world regions. Cyberpsychol Behav Soc Netw. 2014 Dec;17(12):755-60. doi: 10.1089/cyber.2014.0317. PubMed PMID: 25489876; PubMed Central PMCID: PMC4267764.[PubMed]

10. Goel D, Subramanyam A, Kamath R. A study on the prevalence of internet addiction and its association with psychopathology in Indian adolescents. Indian J Psychiatry. 2013 Apr;55(2):140-3. doi:

11. 4103/0019-5545.111451. PubMed PMID: 23825847; PubMed Central PMCID: PMC3696236.[PubMed] 9. Chathoth V, Kodavanji B, Arunkumar N, Pai SR. Internet Behaviour Pattern In Undergraduate Medical 
Students In Mangalore. Int J Innov Res Sci Eng Technol 2013;2.

12. Internet usage worldwide- statistics \& facts https://www.statista.com

13. Surfing and Site Guide:Internet World Stats. http://www.internetworldstats.com/surfing.ht m. Archived at: http://www.webcitation.org/6n6oI9PgG

14. Pontes HM, Patrão IM, Griffiths MD. Portuguese validation of the internet addiction test: An empirical study. J Behav Addict. 2014;3:107-14. [PMC free article] [PubMed]

15. Frangos CC, Frangos CC, Sotriopoulos L. Vol. 1. London, UK: 2012. A Meta Analysis of the Reliability of Youngs Internet Addiction Test. Proceedings of the World Congress on Engineering.

16. Paul AVR, Ganapthi CK, Duraimurugan M, Abirami V, Reji E. Internet Addiction and Associated Factors: A Study among College Students in South India. DOI: http://dx.doi.org/10.15520/ijmhs.2015.vol5.is s3.72.121-125.

17. Krishnamurthy S, Chetlapalli SK. Internet addiction: Prevalence and risk factors: A cross-sectional study among college students in Bengaluru, the Silicon Valley of India. Indian J Public Health. 2015;59:11521. [PubMed]. 